\title{
Self-compassion of street children based on Gender, age, and education
}

\author{
Liza Marini, Rahma Yurliani, Indri Kemala Nasution \\ Departement of Developmental Psychology, Faculty of Psychology \\ University of Sumatera Utara \\ Medan, Indonesia
}

\begin{abstract}
This research aimed to describethe self-compassion of street children in Medan City regarding demographic data,namely gender, age, and education. Subjects involved in this study were 300 street children, aged 12-18 years and attended both formal and non-formal education. The sample of this study was selected by using incidental sampling technique. The data was collected through the spreading of self-compassion questionnaires. The self-compassion scale was developed based on self-compassion theory by Kristin Neff, composed of three components: self-kindness vs. self-judgment, common humanity vs. isolation, and mindfulness vs. over-identification. The data were processed by using One Way ANOVA statistical analysis. The results showed that self-compassion of street children differ significantly regarding education, where subjects with non-formal education have the highest self-compassion compared to subjects with elementary, junior high, and high school / vocational education. Whereas regarding gender and age, the results showed that selfcompassion of street children does not differ significantly.
\end{abstract}

Keywords: Self-compassion, gender, age, education, street children

\section{INTRODUCTION}

Street children are someone under the age of 18 who spends some or all of his time on the streets by engaging in activities to earn money or to sustain his life (Shalahuddin, 2000). Street children are some of the children who live and grow on the streets without any monitoring and growing independently (Irwanto in Sindawati, 2012). The existence of street children in the city of Medan has become a phenomenon that often raises various responses from the public, both positive and negative (Andriansyah, 2011).

Based on the results of the field study, Surbakti (in Puspareni, 2012) distinguished street children in 3 categories of groups. The first group category is children on the street (street children who still have family connections, although the frequency of meetings cannot be ascertained). The second group category is children of the street (street children who have no family relationship or sever ties with family), and the third group category is children from families of the street (street children from street families).

There are no definitive figures on the number of street children these days.Komisi Perlindungan Anak Indonesia (KPAI - The Commission for the Protection of Indonesian Children) estimated that in 2006 there were about 150 thousand street children in Indonesia with the largestconcentration in Jakarta.Based on data obtained from the Social Service of Medan City in 2009 , the number of street children was around 895 (Social Service, 2009). In 2010, the number of street children in Medan began to decrease. They switched professions to improve their family's economic status and social status. Some of them switched professions to angkot drivers or parking attendants. In 2012-2013 the number of street children in Medan did not reach 800 people (KKSP, Personal Communication).

So many problems are underlying the economy of street children. Economic imbalances experienced by street children occurred because of problems that often arise in the family, such as a divorced parent then the mother leaves her child, sick father, and deceased mother, there is also father who is a drunk and addict while the mother is only a washer so that the child must bear the responsibility to help his mother and sister.Another reason that underlies children to decide to become street children is due to aconflict with parents. The children do not want to get involved with the rules at home; they want to find freedom.Many children also choose to become street children because they are rejected by their families with the reason the child had made mistakes such as drug abuse (KKSP, Personal Communications). Street children's lifestyle educates themselves to sell compassion, which will give birth to damaged mentalities which become thicker when they mature (Purba, 
2015). If this happens, it will give birth to more social problems and crime levels in society.

Each has his or her judgment about the problems in his or her lives. Individuals also assess how to cope with the demands of daily needs fulfillment and family demands (Ivancevich, Konopaske, \& Matteson, 2005). Happy and unhappy individuals have differences in response to events in their daily lives and situations (Lyubomirsky in Ulfah, 2015).Happy individuals will see, evaluate, and think about every event in life through a more positive outlook, taking wisdom in every event even if experiencing unpleasant events, and life focusing in the present (Lyubomirsky, 2001 in Ulfah, 2015). The happiness can be explained by some psychological concepts. One psychological concept that is thought to be able to explain it is the concept of self-compassion.

The concept of self-compassion is a concept that adheres to the affection associated with the individual self as the object of attention when faced with negative events (Neff, 2003a). In general, self-compassion associated with openness and understanding toward others. Individuals who have high self-compassion have characteristics; being able to accept oneself whether they are advantages or weaknesses, able to accept mistakes or failures as a natural thing that is also experienced by others, and have an awareness of the connection between everything (Hidayati\& Maharani, 2013).

Self-compassion can explain how individuals can survive, understand, and realize the meaning of a difficulty as a positive thing (Diana, 2015).By having self-compassion, the challenges faced by street children such as; stigma given by the community, violence, an unflattering view by considered lowlife for being accused of being a wild child or a prostitute, as well as discrimination in many ways, especially in access to services which has become a daily consumption, will be easier to get through.It happens because the individual with selfcompassion is not easy to blame themselves when faced with an unpleasant situation, correct mistakes, change behavior to be productive, and dare to face new challenges.

Self-compassion is divided into three components: self-kindness, common humanity, and mindfulness (Neff, 2011). Street children who have self-kindness components will be able to remain good to themselves, not over-criticizing themselves in the negative events they experience. Common humanity component will be possessed when street children can feel that others have also experienced unpleasant circumstances experienced by individuals so that individuals do not feel isolated. The final component of self-compassion is mindfulness. If street children can have this last component, then they will see clearly and accept what is happening now as a balanced thing that will be useful for the future life. Self-Compassion is influenced by internal factors such as age and gender as well as external factors such as environment and culture.

\section{RESEARCH METHODS}

This research used adescriptive method that aimed to describe the research's subject. Based on data from the variables obtained from the subjects that studied and not intended for hypothesis testing. The sample used in this study is a sample that matches the characteristics of the population, namely: street children, adolescents aged 12-18 years and domiciled in Medan. The sampling technique used in this research is incidental sampling technique. The data were collected using a Self-Compassion scale developed based on self-compassion theory by Kristin Neff. The results of the study were processed by using One Way ANOVA statistical analysis assisted by SPSS version 17.0 for Windows program.

\section{RESULTS AND DISCUSSION}

The results showed that the self-compassion of street children differed significantly when viewed from education, where subjects with nonformal education had the highest self-compassion compared to subjects with elementary, junior and senior high school / vocational education. It explains that even though street children have bigger problems, difficulties, or life failures, they will always be looking for ways to solve their problems. The ability to solve problems, failures, and difficulties can be attributed to adversity quotient. Stoltz (in Diana, 2008) stated that individuals who are used to being in a difficult environment would have greater adversity quotient because of better experience and adaptability in overcoming problems. From these statements, it can be concluded that the problems, difficulties, or greater failure of life will improve the adaptability of street children in Medan to solve the problem so it can improve the self-compassion of Medan street children, although they do not run formal education.

Whereas regarding gender and age, the results showed that street children's self-compassion does not differ significantly. In general, the 
results of research conducted by Yarnell, Stafford et al. (2015) showed that there are gender differences that affect the level of selfcompassion, in which males are found to have a slightly higher level of self-compassion than women.However, from the results of this study, the number of men and women are not balanced (proportional), so that affects the result. If viewed from age, all these street children are still in the same period of development which is adolescence, where adolescence is the period of life in which the self-compassion level is at the lowest level compared to other life periods (Neff, 2003). It is based on the improvement of cognitive abilities of adolescents such as increased introspection, metacognition, selfreflection, and thinking ability from a social perspective (Keating 1990, Neff, 2003) also brings new obligations and different developmental tasks. This new ability in adolescents makes them continually evaluate themselves and compare themselves with others because they seek to establish their identity and place within the social hierarchy (Brown \&Lohr, 1987; Harter, 1990 in Neff, 2003).

\section{CONCLUSIONS AND RECOMMENDATIONS}

Based on the results of One Way ANOVA statistical analysis of self-compassion on street children in terms of gender, age and education in the city of Medan, research results were obtained that the self-compassion of street children differed significantly when viewed from the education, where the subject with non-formal education has the highest self-compassion compared to subjects with elementary, junior high and high school / vocational education. Whereas regarding gender and age, the results showed that street children's selfcompassion does not differ significantly.

Suggestions in this research are to the government, especially Medan City Social Service, can realize programs to improve self-compassion on street children by developing and improving facilities and infrastructures such as selfdevelopment for street children, so their life does not end in the streets.The development of informal education programs, the development of creativity, and others are needed by the street children. Mini-libraries with interesting books can also be built, so street children have more useful activities in their spare time.

\section{REFERENCES}

[1] Andriansyah .(2011). AnakJalanan (Studikasusataspersoalan sosial). https://www.scribd.com/doc/74394202 /Fenomena-Anak-Jalanan-Di-Kota-Medan.

[2] DinasSosial Kota Medan. (2009). disosnaker.pemkomedan.go.id/.

Diaksespada 05 November 2016.Di Lempuyangan Yogyakarta. JurnalPks Vo. 11 No.2 Juni 2012. Yogyakarta: KementerianSosial.

[3] Diana, Nida'u. (2008).

StudiDeskriptifTentangAdversity

QuotientPadaSiswaKelasAkselerasi

SekolahMenegahAtasNegeri 1 Malang (SMA N 1 Malang). Skripsi. Malang: Universitas Islam Negeri Malang.

[4] Hidayati, Diana. (2015). Self CompassiondanLoneliness. Malang. No. 1/ Vol. 3/ January 2015. Malang: UniversitasMuhammadiah Malang.

[5]Hidayati, F., dan Maharani, R. (2013). Self compassion(welasasih):

Sebuahalternatifkonsep transpersonal tentangsehat spiritual menujudiri yang utuh. Prosidingpsikologikesehatan.

Semarang:

UniversitasKatolikSoegijapranata

Semarang.

[6] Ivancevich, J.M., Konopaske,R., \&Matteson,M. (2005). Organizational behavior and management. Mc Graw-Hill: New York.

[7]Neff, K. D. (2003). Self-compassion: An alternative conceptualization of a healthy attitude toward oneself. Self and Identity, 2, 85-102.

DOI: $10.1080 / 15298860390129863$.

[8] Neff, K. D. (2003a). The development and validation of a scale to measure selfcompassion. Self and Identity, 2,223250.DOI: 10.1080/15298860390209035. 
[9] Neff, K.D. (2011). Self-compassion: stop beating yourself up and leave insecurity behind. New York: Harper Collins Publisher.

[10] Purba, RiantoDaud. 2015. PerilakuSeksBebaspadaAnakJalananDlama PerspektifKriminologi. Skripsi. Medan: Universitas Sumatera Utara.

[11] Puspareni, Yuniar. (2012). ImpianAnakJalanan (studieksplorasitentangOrientasi Masa DepanAnakJalanan). Skripsi. Yogyakarta: UniversitasNegeri Yogyakarta.

[12] Shalahuddin, Odi. (2010). Fenomena Anak Jalanan Kota Medan; Problematika dan Solusinya (Sebuah studi tematik terhadap permasalahan Anak Jalanan; Antara tuntutan dan kebebasan hidup).https://odishalahuddin.wordpress.c om/2010/01/04/anak-jalanan-studikasus-atas-persoalan-sosial/.

[13] Sindawati, Iin. (2012). Faktor-faktor yang MempengaruhiperilakuSeksualPadaAnakjal anan di YayasanGirlan Nusantara Sleman. Skripsi. Yogyakarta: Sekolah Tinggi IlmuKesehatan 'Aisyiyah Yogyakarta

[14] Ulfah, Khadhra. (2015). HubunganSelfCompassiondenganSubjective WellBeingpadaMahasiswaUniversitas Sumatera Utara. Skripsi. Medan: Universitas Sumatera Utara.

[15] Yarnell, Stafford. (2015). Meta Analysis of Gender Differences in Self Compassion. DOI: 10.1080/15298868.2015.1029966 